\title{
Synthesis of Aza Derivatives of Isomers of Angular and Complex Phenothiazine Rings
}

\author{
BENJAMIN E. EZEMA ${ }^{1 *}$, CHIDIMMA G. EZEMA², JUDE I. AYOGU ${ }^{1}$, \\ DAVID I. UGWU ${ }^{1}$ and EFETURI A. ONOABEDJE ${ }^{1}$
}

\author{
${ }^{1}$ Department of Pure and Industrial Chemistry, \\ Faculty of Physical Sciences, University of Nigeria, Nsukka, Nigeria. \\ ${ }^{2}$ National Centre For Energy Research and Development, University of Nigeria, Nsukka, Nigeria. \\ *Corresponding author E-mail: benjamin.ezema@unn.edu.ng \\ http://dx.doi.org/10.13005/ojc/310145
}

(Received: November 12, 2014; Accepted: December 04, 2014)

\begin{abstract}
Isomeric derivatives of angular aza benzophenothiazine and complex aza benzothiazinophenothiazine rings were successfully synthesized. Reactions of 2-amino-3,5dibromopyrazine with 6,7-dibromoquinoline-5,8-dione in anhydrous sodium carbonate gave isomeric angular aza benzophenothiazine compounds 6,9-dibromo-1,8,11-triazabenzo[a]phenothiazine5-one and 6,9-dibromo-4,8,11-triazabenzo[a]phenothiazine-5-one. Further reactions of these compounds, in the first case, respectively with 2-amino-6-methoxypyridin-3-thiol gave the two isomeric aza complex compounds identified as 13-bromo-8-methoxy-1,9,12,15tetraazabenzo[a][1,4]benzothiazino[3,2-c]phenothiazine and 13-bromo-8-methoxy-4,9,12,15tetraazabenzo[a][1,4]benzothiazino[3,2-c]phenothiazine. Secondly, reactions of the same angular benzophenothiazine compounds with 4-aminopyrimidin-5-thiol gave two more complex compounds 13-bromo-1,6,8,12,15-pentaazabenzo[a][1,4]benzothiazino[3,2-c]phenothiazine and 13-bromo4,6,8,12,15-tetraazabenzo[a][1,4]benzothiazino[3,2-c]phenothiazine. The compounds have very intense colours.
\end{abstract}

Keywords: anhydrous sodium carbonate; 2-amino-3,5-dibromopyrazine; 2-amino-6-methoxypyridin5-thiol; 4-aminopyrimidin-5-thiol; 6,7-dibromoquinoline-5,8-dione; condensation reaction.

\section{INTRODUCTION}

Phenothiazine 1 structural modifications has been successfully utilized in the design of variety of pharmaceuticals that are clinically used for antitubercular activity ${ }^{1}$, cholinesterase inhibitor ${ }^{2}$, histamine antagonist ${ }^{3}$ and multiple drug resistance reverting agent ${ }^{4}$. The applications of phenothiazines also range from pesticides; dyes in paint and textile industries, industrial antioxidants ${ }^{5-6}$ etc. Side substituted phenothiazine derivatives are also of great interest because of their photophysical and optoelectrochemical properties ${ }^{7-9}$. Promazine, for instance, has high toxicity and causes tension. To reduce these adverse effects, structural modifications of the phenothiazine ring have been 
reported and the synthesis of its aza-analogues continued. Therefore incorporation of one, two, three or four nitrogen atoms in the rings is very necessary. Although some successful preparations of the angular system $\mathbf{2}$ and three-branched system $\mathbf{3}$ have been reported ${ }^{10-13}$, the search for more derivatives is still in progress. The authors here report the successful synthesis of two isomeric derivatives of angular aza benzophenothiazine and two complex aza benzothiazinophenothiazine rings.<smiles>c1ccc2c(c1)CNc1ccccc1S2</smiles><smiles>c1ccc2c(c1)Nc1c(ccc3ccccc13)S2</smiles>

2

\section{EXPERIMENTAL}

The solvents and chemicals were of analytical grade purity. They were purchased from Sigma-Aldrich chemicals and were used without further purification. The reactions were monitored with TLC. Purity of the compounds was ascertained with TLC. Melting points were recorded on Fischer Jone's melting point apparatus. Uv-visible spectra were recorded on JENWAY 6405 spectrophotometer (solvent methanol). Infrared spectra were recorded on an FTIR-8400S infrared spectrophotometer using $\mathrm{KBr}$ discs. ${ }^{1} \mathrm{H}-\mathrm{NMR}$ and ${ }^{13} \mathrm{C}-\mathrm{NMR}$ were recorded on Brucker Av instrument $300 \mathrm{MHz}$; chemical shifts were reported on ( $\delta \mathrm{ppm})$ scale. Microanalysis was obtained on Carlos Erba Elemental Analyser EA 1108.

\section{5-Nitrosoquinolin-8-ol}

A solution of quinoline-8-ol (40 g, 0.27 moles) in water $(120 \mathrm{~mL})$ and concentrated hydrochloric acid $(45 \mathrm{~mL})$ in $500 \mathrm{ml}$ beaker was immersed in ice-salt bath. $120 \mathrm{~g}$ of ice was later added. The mixture was then treated with a cold solution of sodium nitrite $(20 \mathrm{~g})$ in water $(75 \mathrm{~mL})$ for a period of $2 \mathrm{~h}$ at $0-4{ }^{\circ} \mathrm{C}$ to give a bright yellow solid previously reported ${ }^{12}$.

\section{5-Aminoquinolin-8-ol sulphate}

5-nitrosoquinolin-8-ol hydrochloride $(0 \mathrm{~g}$, $0.22 \mathrm{mmol}$ ) was dissolved in a solution of water (160 $\mathrm{mL})$ and $5 \mathrm{M}$ sodium hydroxide $(260 \mathrm{~mL})$. The solution was heated to $40{ }^{\circ} \mathrm{C}$ with stirring and calculated amount of sodium dithionite $(95 \mathrm{~g})$ was later added and the temperature rose to $70-80^{\circ} \mathrm{C}$. Nitrogen gas<smiles></smiles>

was bubbled through the solution for $10 \mathrm{~min}$ and it was allowed cooling to $50{ }^{\circ} \mathrm{C}$. Thereafter, $6 \mathrm{M}$ sulphuric acid $(250 \mathrm{~mL})$ was added to the solution with evolution of sulphur oxide observed. The reaction mixture was maintained under reduced pressure with stirring until the gaseous evolution stopped. The mixture was cooled and the resulting precipitate collected by filtration. The filtrate was further chilled for more days in freezer and filtered to obtain light tan powder, m.p. $220^{\circ} \mathrm{C}$

\section{6,7-Dibromoquinoline-5,8-dione}

$24 \%$ aqueous hydrobromic acid $(400 \mathrm{~mL})$ was added to 5 -aminoquinolin-8-ol sulphate (54 g, $0.34 \mathrm{mmol}$ ) in a 2-litre reaction flask attached to a condenser and dropping funnel. A solution of potassium bromate (38.5 g, $0.29 \mathrm{mmole})$ in water $(150 \mathrm{~mL}$ ) was added drop wise from the funnel and the reaction temperature was maintained at 50-60 ${ }^{\circ} \mathrm{C}$ and heated for further $30 \mathrm{~min}$. At the end of reaction, the mixture was allowed to cool, poured into crushed ice $(500 \mathrm{~g})$, chilled, filtered and the residue collected. The filtrate was further chilled in freezer for several days and more residues collected and recrystallized from aqueous chloroform/ethyl acetate to give orange-brown powder, mp 242-243 (lit. 245). [14]

\section{6,9-dibromo-1,8,11-triazabenzo[a]phenothiazine- 5-one (9) and 6,9-dibromo-4,8,11-triazabenzo [a]phenothiazine-5-one (10)}

2-amino-5-bromopyrazin-3-thiol $(6.10 \mathrm{~g}$, $30 \mathrm{mmol}$ ) was weighed into a reaction flask attached to a reflux condenser and thermometer. Anhydrous sodium carbonate $(3.20 \mathrm{~g})$ was also added followed 
by addition of benzene (150 mL) and DMF (20 mL). The mixture was warmed to dissolve; 6,7dibromoquinoline-5,8-dione (4.62 g, $15 \mathrm{mmol}$ ) was later added and the reaction mixture refluxed with continuous stirring for $7 \mathrm{~h}$. During the reaction period, the reaction mixture was sported on precoated TLC plate every $1 \mathrm{~h}$ interval. At the end of reaction, the solvent was removed. Water was added to the slurry, warmed and stirred to dissolve the inorganic salt. The mixture was allowed to stand overnight, then filtered and subjected to column chromatography packed with alumina and eluted with benzene/ethyl acetate. The fractions were further purified from aqueous methanol/acetone and the purity ascertained by spotting on tlc to give $\mathbf{9}$ as white-red powder and $\mathbf{1 0}$ as reddish powder.

\section{6,9-dibromo-1,8,11-triazabenzo[a]phenothiazine-} 5-one (9).

M. $\mathrm{p}>250^{\circ} \mathrm{C}$ (dec): UV-visible (MeOH); $\lambda$ $\max : 450,380,330,285,250,210$; FT-IR spectrum absorption bands at $1670 \mathrm{~cm}^{-1}(\mathrm{C}=\mathrm{O})$ and $1590 \mathrm{~cm}$ ${ }^{1}(-\mathrm{C}=\mathrm{N}),{ }^{1} \mathrm{H}-\mathrm{NMR}\left(\mathrm{CDCl}_{3}, \mathrm{ppm}\right): 8.50(\mathrm{~s}, 1 \mathrm{H}), 8.80-$ $8.85(\mathrm{~m}, 2-\mathrm{H}, 3-\mathrm{H}, 4-\mathrm{H}),{ }^{13} \mathrm{C}-\mathrm{NMR}\left(\mathrm{CDCl}_{3}, \delta \mathrm{ppm}\right)$ : 183.12, 165.74, 163.10, 160.08, 157.73, 153.24, $150.13,148.08,145.30,137.04,132.54,126.23$, 115.84. Elemental analysis calculated for $\left(\mathrm{C}_{13} \mathrm{H}_{4} \mathrm{~N}_{4} \mathrm{Br}_{2} \mathrm{OS}\right): \%$ : C, 36.82; $\mathrm{H}, 0.95 ; \mathrm{N}, 13.21 ; \mathrm{Br}$, 37.68; S, 7.56, Found: \%; C, 36.86; H, 0.95; N, 13.25; $\mathrm{Br}, 37.67 ; \mathrm{S}, 7.54$

6,9-dibromo-4,8,11-triazabenzo[a]phenothiazine5-one (10)

M.p. $>265^{\circ} \mathrm{C}$ (dec): UV-visible $(\mathrm{MeOH}) ; \lambda$ $\max : 465,387,320,280,253,213$. FT-IR spectrum absorption bands at $1670 \mathrm{~cm}^{-1}(\mathrm{C}=\mathrm{O})$ and $1590 \mathrm{~cm}^{-}$ ${ }^{1}(-\mathrm{C}=\mathrm{N}),{ }^{1} \mathrm{H}-\mathrm{NMR}\left(\mathrm{CDCl}_{3}, \mathrm{ppm}\right): 8.52(\mathrm{~s}, 1 \mathrm{H}), 8.87-$ $8.92(\mathrm{~m}, 1-\mathrm{H}, 2-\mathrm{H}, 3-\mathrm{H})\left({ }^{13} \mathrm{C}-\mathrm{NMR}\left(\mathrm{CDCl}_{3}, \delta \mathrm{ppm}\right)\right.$ : 183.12, 165.74, 163.10, 160.08, 157.73, 155.37, 151.28, 145.43, 142.32, 140.10, 136.54, 126.23, 115.84. Elemental analysis calculated for $\left(\mathrm{C}_{13} \mathrm{H}_{4} \mathrm{~N}_{4} \mathrm{Br}_{2} \mathrm{OS}\right)$ : \%: C, 36.82; $\mathrm{H}, 0.95 ; \mathrm{N}, 13.21 ; \mathrm{Br}$, 37.68; S, 7.56, Found: \%; C, 36.86; H, 0.95; N, 13.25; $\mathrm{Br}, 37.67 ; \mathrm{S}, 7.54$

\section{General Procedure for Synthesis of Complex Compounds}

2--amino-6-methoxypyridin-3-thiol (1.0 g, $6 \mathrm{mmol}$ ) was weighed into a reaction flask attached to a reflux condenser and thermometer. Anhydrous sodium carbonate $(1.0 \mathrm{~g})$ was also added followed by addition of 1,4-dioxane (80 $\mathrm{mL})$ and DMF (10 $\mathrm{mL})$. The mixture was warmed to dissolve, then 6,9-dibromo-1,8,11-triazabenzo[a]phenothiazine5-one: $(2.70 \mathrm{~g}, 6 \mathrm{mmole})$ was added and the reaction mixture refluxed with continuous stirring for $9 \mathrm{~h}$ as described for the reaction above. During the reaction period, the reaction mixture was sported on TLC plate every $1 \mathrm{~h}$ interval. At the end of reaction, water was added to the slurry and stirred to dissolve the inorganic salt. The mixture was chilled, then filtered and recrystallized from aqueous DMF/acetone to give the titled product

13-bromo-8-methoxy-1,9,12,15-tetraazabenzo [a][1,4]benzothiazino[3,2-c]phenothiazine (12)

The above procedure was employed and the product obtained as dark red solid; $\mathrm{mp}>300$ ${ }^{\circ} \mathrm{C}$. UV-visible $(\mathrm{MeOH}) \lambda_{\text {max }}: 680,570,510,450$, 380, 320, 280, 250; FT-IR spectrum gave absorption bands at $1540 \mathrm{~cm}^{-1}(\mathrm{C}=\mathrm{C}, \mathrm{Ar})$ and $1580 \mathrm{~cm}^{-1}(-\mathrm{C}=\mathrm{N})$; ${ }^{1} \mathrm{H}$-NMR spectrum (DMSO-d 6 , $\left.\delta \mathrm{ppm}\right): 3.80\left(\mathrm{~s}, \mathrm{CH}_{3}\right)$, $6.80(\mathrm{~d}, 8-\mathrm{H}), 7.55(\mathrm{~d}, 9-\mathrm{H}), 8.55(\mathrm{~s}, 13-\mathrm{H}), 8.75-$ 8.79 (m, 2-H, 3-H, 4-H); ${ }^{13} \mathrm{C}-\mathrm{NMR}$ (DMSO ' ppm): $157.12,155.10,154.34,154.15,148.32$, '144.14, 144.08, 143.67, 138.23, 134.76, 132.83, 130.04, 128.24, 124.32, 122.56, 118.64, 47.73. Elemental analysis calculated for $\left(\mathrm{C}_{19} \mathrm{H}_{9} \mathrm{~N}_{6} \mathrm{BrOS}_{2}\right): \%: 47.41$; H, 1.88; N, 17.46; Br, 16.60; S, 13.32, Found: \%; C, 47.48; H, 1.88; N, 17.43; Br, 16.65; S, 13.28.

13-bromo-8-methoxy-4,9,12,15-tetraazabenzo [a][1,4]benzothiazino[3,2-c]phenothiazine (13)

The same protocol as in $\mathbf{3 . 5}$ to obtain $\mathbf{1 3}$ as purple-red solid; $\mathrm{mp}>300^{\circ} \mathrm{C}$ : UV-visible $(\mathrm{MeOH}) ; \lambda$ max $: 672,581,520,450,390,320,280,255,220$. FT-IR spectrum $1576 \mathrm{~cm}^{-1}(\mathrm{C}=\mathrm{C}, \mathrm{Ar})$ and $1585 \mathrm{~cm}^{-1}(-\mathrm{C}=\mathrm{N})$ respectively; ${ }^{1} \mathrm{H}-\mathrm{NMR}$ spectrum (DMSO-d $\left.\mathrm{d}_{6}, \mathrm{ppm}\right): 3.80$ (s, $\left.\mathrm{CH}_{3}\right), 6.80$ (d, 8-H), 7.55 (d, 9-H), $8.55(\mathrm{~s}, 13-\mathrm{H})$, 8.75-8.79 (m, 1-H, 2-H, 3-H); ${ }^{13} \mathrm{C}-\mathrm{NMR}$ (DMSO $\delta$ ppm): 156.12, 155.10, 154.34, 154.15, 148.32, 144.14, 144.08, 143.67, 138.23, 134.76, 132.83, 130.04, 128.24, 124.32, 122.56, 118.64, 49.73. Elemental analysis calculated for $\left(\mathrm{C}_{19} \mathrm{H}_{9} \mathrm{~N}_{6} \mathrm{BrOS}_{2}\right)$ : \%: C, 47.41; H, 1.88; N, 17.46; Br, 16.60; S, 13.32, Found: \%; C, 47.48; H, 1.88; N, 17.43; Br, 16.65; S, 13.28.

13-bromo-1,6,8,12,15-pentaazabenzo[a] $[1,4]$ benzothiazino $[3,2-c]$ phenothiazine (15) 4-aminopyrimidin-5-thiol $(1.0 \mathrm{~g}, 8 \mathrm{mmol})$ 
reacted with 6,9-dibromo-4,8,11-triazabenzo [a]phenothiazine-5-one: $(3.34 \mathrm{~g}, 8 \mathrm{mmol})$ to give purple dark-red solid; $\mathrm{mp}>300^{\circ} \mathrm{C}$. FT-IR spectrum $1570 \mathrm{~cm}^{-1}(\mathrm{C}=\mathrm{C}, \mathrm{Ar})$ and $1593 \mathrm{~cm}^{-1}(-\mathrm{C}=\mathrm{N})$ respectively. UV-visible $(\mathrm{MeOH}) ; \lambda_{\text {max }}: 687,570,530$, 480, 386, 340, 280, 23; 'H-NMR spectrum (DMSO$\left.\mathrm{d}_{6}, \mathrm{ppm}\right): 8.55(\mathrm{~s}, 13-\mathrm{H}), 8.62(\mathrm{~s}, 7-\mathrm{H}), 8.90(\mathrm{~s}, 9-\mathrm{H})$, 8.73-8.76 (m, 2-H, 3-H, 4-H), ${ }^{13} \mathrm{C}-\mathrm{NMR}$ (DMSO $\delta$ ppm): 162.12, 161.10, 160.34, 160.15, 159.32, $158.34,156.08,153.67,148.23,144.76,138.83$, 132.04, 128.24, 124.32, 122.56, 119.64. Elemental analysis calculated for $\left(\mathrm{C}_{17} \mathrm{H}_{6} \mathrm{~N}_{7} \mathrm{BrS}\right)$ : \%: C, 45.14; $\mathrm{H}, 1.34$; N, 21.68; $\mathrm{Br}, 17.67 ; \mathrm{S}, 14.18$, Found: \%; C, 45.19; H, 1.34; N, 21.70; Br, 17.69; S, 14.15.

\section{3-bromo-4,6,8,12,15-tetraazabenzo[a]} $[1,4]$ benzothiazino[3,2-c]phenothiazine (16)

Reddish-dark brown solid; $\mathrm{mp}>300{ }^{\circ} \mathrm{C}$ : FT-IR spectrum $1576 \mathrm{~cm}^{-1}(\mathrm{C}=\mathrm{C}, \mathrm{Ar})$ and $1595 \mathrm{~cm}^{-1}$ $(-\mathrm{C}=\mathrm{N})$ respectively. UV-visible $(\mathrm{MeOH}) ; \lambda_{\max }: 701$, 670, 524, 450, 360, 324, 281, 262, 215. ' ${ }^{1 H}$-NMR spectrum (DMSO-d, ppm): 8.55 (s, 13-H), 8.62 (s, 7-H), $8.90(\mathrm{~s}, 9-\mathrm{H}), 8.73-8.76(\mathrm{~m}, 1-\mathrm{H}, 2-\mathrm{H}, 3-\mathrm{H})$, ${ }^{13} \mathrm{C}-\mathrm{NMR}$ (DMSO $\delta \mathrm{ppm}$ ): 162.12, 161.10, 160.34, $160.15,159.32,157.14,156.08,153.67,148.23$, 144.76, 138.83, 132.04, 128.24, 124.32, 122.56, 119.64. Elemental analysis calculated for $\left(\mathrm{C}_{17} \mathrm{H}_{6} \mathrm{~N}_{7} \mathrm{BrS}_{2}\right): \%$ : C, 45.14; $\mathrm{H}, 1.34 ; \mathrm{N}, 21.68 ; \mathrm{Br}$, 17.67; S, 14.18, Found: \%; C, 45.19; H, 1.34; N, 21.70; $\mathrm{Br}, 17.69 ; \mathrm{S}, 14.15$.

Dyeing with the compounds $9,10,12,13,15$ and 16 One of the dye compounds $(0.20 \mathrm{~g})$ was weighed into a reaction flask attached to reflux condenser and a thermometer. Acetone $(60 \mathrm{~mL})$ was added and mixture warmed in water bath to dissolve, little volume of DMF $(5.0 \mathrm{~mL})$ was also added to aid complete dissolution. Sodium dithionite $(5.0 \mathrm{~g})$ was later added and the mixture refluxed for $2 \mathrm{~h}$ and allowed to cool to $40^{\circ} \mathrm{C}$. A piece of rayon fabric was inserted into the solution followed by addition glacial acetic $(5.0 \mathrm{~mL})$ and the mixture refluxed with gradual increase in temperature and occasional agitation for further $1 \mathrm{~h}$. It was quickly cooled to room temperature and the fabric was removed and air dried. The same procedure was carried out with other dye compounds.

\section{Wash fastness test}

A specimen of the air dried dyed fabric was sewed between pieces of undyed rayon and cotton fabrics of equal size and were mechanically agitated in wash wheel in soap solution at $60^{\circ} \mathrm{C}$ for $30 \mathrm{~min}$ The change in colour of the dyed material and the staining on the undyed materials was accessed according to the international geometric gray scale ( 1 for poor and 5 for excellent fastness) and recorded as presented in the table.

\section{Fastness to sublimation}

A specimen of the dried dyed fabric was sewed between a piece of undyed rayon fabric and cotton fabric of equal size. It was treated with sublimation fastness tester at $160{ }^{\circ} \mathrm{C}$ for $40 \mathrm{~s}$ and later at $180{ }^{\circ} \mathrm{C}$ for another 40 s and any colour change and stains on two undyed fabrics sewed together was examined base on the international geometric gray standard ( 1 and 5 for poor and excellent respectively) as presented in the table.

\section{RESULTS AND DISCUSSIONS}

Quinoline-8-ol 4 was converted to 5nitrosoquinolin-8-ol hydrochloride $\mathbf{5}$ when treated with a cold solution of sodium nitrite for a period of $2 \mathrm{~h}$ at $0-4{ }^{\circ} \mathrm{C}$. Further reaction of 5 -nitrosoquinolin8-ol hydrochloride 5 with sodium dithionite in aqueous sodium hydroxide and precipitation with sulphuric acid gave 5 -aminoquinolin-8-ol sulphate 6.

When aminoquinolin-8-ol sulphate 6 was subsequently treated with solution of potassium bromate in aqueous hydrobromic acid at $50-60{ }^{\circ} \mathrm{C}$ for $30 \mathrm{~min}$; 6,7-Dibromoquinoline-5,8-dione 7 was produced in good yield (scheme 1):

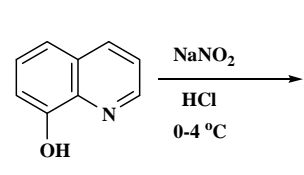

4

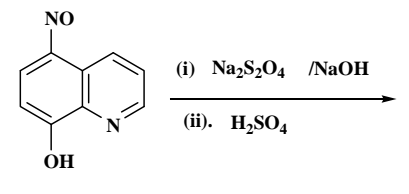

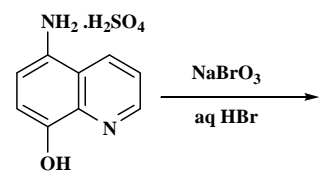

6<smiles>O=C1C(=O)c2ncccc2C(=O)C(Br)=C1Br</smiles>

7

Scheme 1: 
2-Amino-5-bromopyrazin-3-thiol 8 was reacted with 6,7-dibromoquinoline-5,8-dione 7 in anhydrous sodium carbonate catalysed condensation reactions to give a mixture of two isomers of angular triazabenzophenothiazines 6,9dibromo-1,8,11-triazabenzo[a]pheno- thiazine-5one 9 and 6,9-dibromo-4,8,11-triazabenzo[a] phenothiazine-5-one 10 separated by column chromatography. FT-IR spectrum gave strong absorption bands at $1670 \mathrm{~cm}^{-1}(\mathrm{C}=\mathrm{O})$ and $1590 \mathrm{~cm}^{-1}$ ${ }^{1}(-\mathrm{C}=\mathrm{N})$ for compound 9 and $1685 \mathrm{~cm}^{-1}(\mathrm{C}=\mathrm{O})$ and $1605 \mathrm{~cm}^{-1}(-\mathrm{C}=\mathrm{N})$ for compound 10 respectively. ${ }^{1} \mathrm{H}$-NMR spectrum gave further evidence of the compounds as follows: compound 9; $\left(\mathrm{CDCl}_{3}, \mathrm{ppm}\right)$ : $8.50(\mathrm{~s}, 1 \mathrm{H}), 8.80-8.85(\mathrm{~m}, 3 \mathrm{H})$, and compound 10 ; $8.52(\mathrm{~s}, 1 \mathrm{H}), 8.87-8.92(\mathrm{~m}, 3 \mathrm{H})$ (Scheme 2):<smiles>Nc1ncc(Br)nc1S</smiles><smiles>O=C1C(Br)=C(Br)C(=O)c2ncccc21</smiles>

7

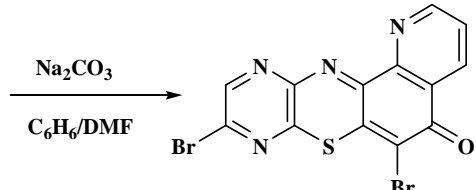

9<smiles>O=c1c(Br)c2sc3nc(Br)cnc3nc-2c2cccnc12</smiles>

Scheme 2:

Further reactions of the isomers separately with 2-amino-6-methoxypyridin-3-thiol $\mathbf{1 1}$ in basic medium as the catalyst for $10 \mathrm{~h}$ gave the complex compounds characterized and identified as 13b r o m o - 8 - m e t h o x y - 1, 9, 12,15 tetraazabenzo[a][1,4]benzothiazino[3,2c]phenothiazine 12 and 13-bromo-8-methoxy4,9,12,15-tetraazabenzo[a][1,4]benzothiazino[3,2c]phenothiazine 13 . The FT-IR spectrum gave very close identical absorption bands at $1540 \mathrm{~cm}^{-1}(\mathrm{C}=\mathrm{C}$, $\mathrm{Ar})$ and $1580 \mathrm{~cm}^{-1}(-\mathrm{C}=\mathrm{N})$ for compound 12; and $1548 \mathrm{~cm}^{-1}(\mathrm{C}=\mathrm{C}, \mathrm{Ar})$ and $1586 \mathrm{~cm}^{-1}(-\mathrm{C}=\mathrm{N})$ for 13 . ${ }^{1} \mathrm{H}-\mathrm{NMR}$ spectrum gave further evidence of the compounds by showing identical signals as follows: compound 12: (DMSO-d $\mathrm{d}_{6}$ ), ppm 3.80 (s, 3H), 6.80 (d, $1 \mathrm{H}), 7.55(\mathrm{~d}, 1 \mathrm{H}), 8.55(\mathrm{~s}, 1 \mathrm{H}), 8.75-8.79(\mathrm{~m}$, $3 \mathrm{H})$, compound 13: $3.80(\mathrm{~s}, 3 \mathrm{H}), 6.80(\mathrm{~d}, 1 \mathrm{H}), 7.55$ $(\mathrm{d}, 1 \mathrm{H}), 8.55(\mathrm{~s}, 1 \mathrm{H}), 8.75-8.79(\mathrm{~m}, 3 \mathrm{H})$ (Scheme 3):

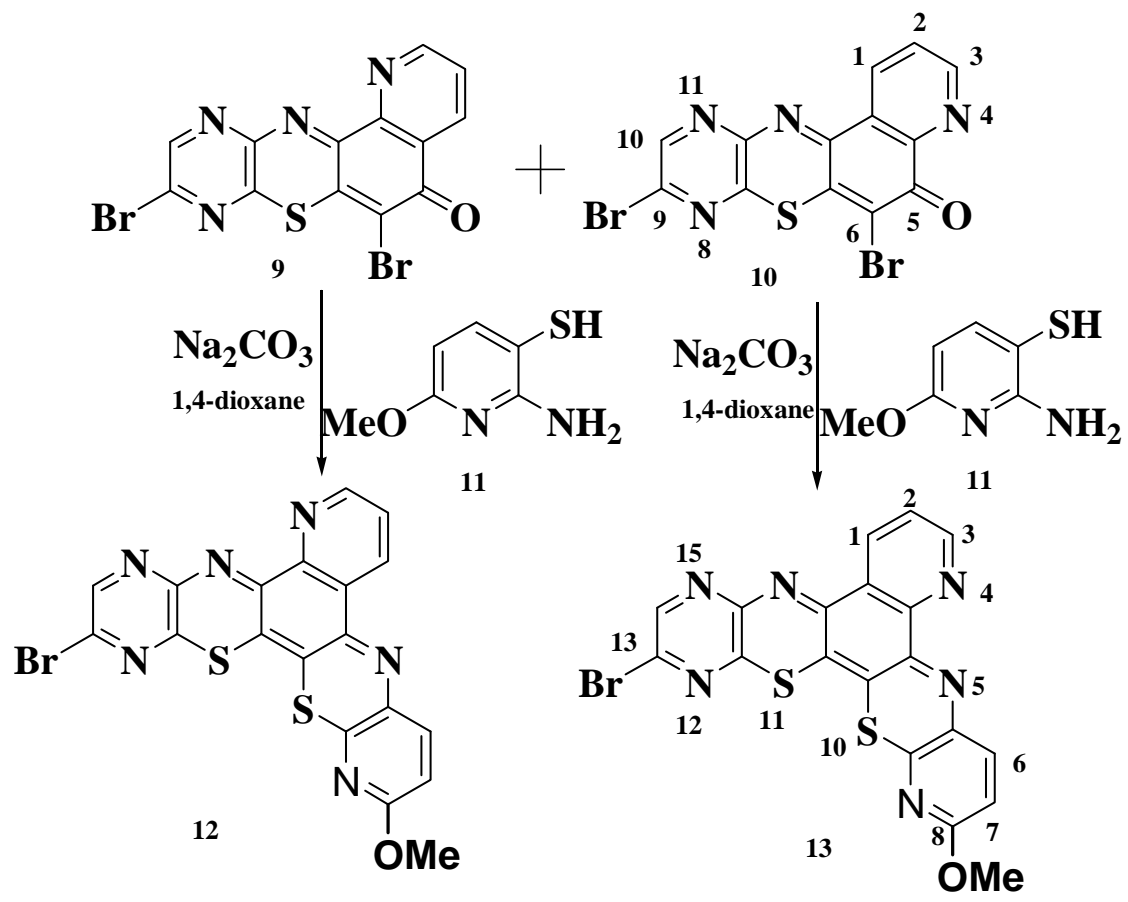

Scheme 3: 
When the angular compounds were later treated with 4-aminopyrimidin-5-thiol 14, two more complex benzothiazinophenothiazine rings 13bromo-1,6,8,12,15-pentaazabenzo[a][1,4] benzothiazino[3,2-c]phenothiazine 15 and 13bromo-4,6,8,12,15-tetraazabenzo[a][1,4] benzothiazino[3,2-c]phenothiazine 16 were obtained. ${ }^{1} \mathrm{H}-\mathrm{NMR}$ spectrum further gave identical signals for compound 15 and 16. (DMSO-d $\mathrm{d}_{6}$ ), ppm $8.55(\mathrm{~s}, 1 \mathrm{H}), 8.62(\mathrm{~s}, 1 \mathrm{H}), 8.90(\mathrm{~s}, 1 \mathrm{H}), 8.73-8.76(\mathrm{~m}$, $3 \mathrm{H})$ : scheme 4.<smiles>O=c1c(Br)c2sc3nc(Br)cnc3nc-2c2ncccc12</smiles><smiles>CC(C)(C)C(C)(C)C</smiles><smiles>C[C@H](CNc1cc(N)ncn1)C(N)=O</smiles><smiles>O=c1c(Br)c2sc3nc(Br)cnc3nc-2c2cccnc12</smiles><smiles>Brc1cnc2c(n1)Sc1c3c(c4ncccc4c1=N2)=Nc1ncncc1S3</smiles>

16

Scheme 4:

\section{Dyeing of Nylon Fabric with Synthesized Dyes}

The new compounds are vat dyes and, therefore, they are applied in their reduced state. Dyeing was carried out in the presence of sodium dithionite and in aqueous solution of acetone/DMF/ acetic acid. They gave well to excellent shades on the rayon fabric and showed excellent wash fastness and good sublimation fastness based on the international geometric gray standard ( 1 for poor and 5 for excellent respectively) as presented in the table.

Table 1: Fastness properties of synthesized heterocyclic dyes

\begin{tabular}{|c|c|c|c|c|c|c|}
\hline \multirow[t]{2}{*}{$\begin{array}{l}\text { Dye } \\
\text { no }\end{array}$} & \multirow{2}{*}{$\begin{array}{c}\text { Wash } \\
\text { fastness } \\
(1-5)\end{array}$} & \multicolumn{2}{|c|}{$\begin{array}{l}\text { Stain on undyed fabric } \\
\text { after washing (1-5) }\end{array}$} & \multirow[t]{2}{*}{$\begin{array}{c}\text { Sublimation } \\
\text { fastness (1-5) }\end{array}$} & \multicolumn{2}{|c|}{$\begin{array}{l}\text { Stain on undyed fabric } \\
\text { after sublimation (1-5) }\end{array}$} \\
\hline & & rayon & cotton & & rayon & cotton \\
\hline 9 & $3-4$ & 3 & $3-4$ & 3 & 3 & 4 \\
\hline 10 & $3-4$ & 4 & $3-4$ & 4 & 3 & 4 \\
\hline 12 & $4-5$ & 4 & $4-5$ & $4-5$ & 4 & $4-5$ \\
\hline 13 & $4-5$ & 4 & $4-5$ & $4-5$ & 4 & $4-5$ \\
\hline 15 & $4-5$ & 4 & 5 & 4 & 4 & $4-5$ \\
\hline 16 & $4-5$ & 4 & 5 & 4 & 4 & $4-5$ \\
\hline
\end{tabular}




\section{CONCLUSION}

We have successfully synthesized two aza derivatives of angular phenothiazine and four more aza derivatives of complex benzothiazinopheno thiazine that has applications in some industries as colourants. Establishment of the structures were based on the data of spectral characterization.

\section{REFERENCES}

1. Bate, A.B; Kalin, J.H; Fooksman, E.M; Amorose, E.L; Price, C.M; Williams, H.M; Rodig, M.J; Cho, M.O; Mitchell, S.H; Wang, W; Franzblau, S.G. Bioorg. Med. Chem. Lett. 2007, 17, 1346.

2. Darvesh, S; Darvesh, K.V; McDonald, R.S; Mataija, D; Walsh ,R; Mothana,S; Lockridge, O; Martin, E. Jour. Med. Chem. 2008, 51, 4200.

3. Kubota, K; Kurebayashi, H; Mayachi, H; Tobe, M; Onishi, M; Isobe, Y. Bioorg. Med. Chem. Lett. 2009, 19, 2766.

4. Bisi, A; Meli, M; Gobbi, S; Rampa, A; Tolomeo, M; Dusonchet, L. Bioorg. Med. Chem. 2008, 16, 6474.

5. Okafor, C.O; Okerelu, O; Okeke, S. I. Dyes and Pigments, 1987, 8, 11.

6. Okafor, C.O. Int. J. Sulfur chem. B. 1971, 18, 239.

7. Weiss, E.A; Tauber, M.J; Kelley, R.F; Ahrens, M.J; Ratner, M.A; Wasielewski, M.R; Jour.
Amer. Chem. Soc. 2005, 127, 11842.

8. Lai, R.Y; Kong, X; Jenekhe, S.A; Bard, A.J. Jour. Amer. Chem. Soc. 2003, 125, 12631.

9. Rhee, H.W; Choi, S.J; Yoo. S.H; Jang, H.O; Park, H.H; Pinto, R.M; Cameselle, J.C; Sandoval, F.J; Roje, S; Han, K; Chung, D.S; Suh, J;Hong, J.I. Jour. Amer. Chem. Soc. 2009, 131, 10107.

10. Okoro U.C.; Ezema, B.E. International Journal of Chem, 2006, 16(2), 115- 120.

11. Ezema, B. E. International Journal of Chem. 2010, 20(2), 119-125.

12. Ezema, B. E.; Ezema, C. G.; Onoabedje E.A.; Ugwu D. I. Chemical and Process Engineering Research, 2013 8, 35-42.

13. Ezema, B. E.; Okafor, C.O.; Ezema, C.G.; Onoabedje, A. E. Chemical and Process Engineering Research, 2012, 3, 40-47

14. Harnath, B. B.; Subba, R. N. V. Heterocycle Compounds Physiol Interest, Hyderabad, India, 1964, 114-118, 